\title{
Effects of Dietary Selenium Source and Storage on Internal Quality of Eggs
}

\author{
Gordana Kralik ${ }^{1}$, Zlata Gajčević ${ }^{1}$, Pavel Suchý ${ }^{2}$ Eva Straková2 ${ }^{2}$ Danica Hanžek ${ }^{1}$ \\ ${ }^{1}$ Josip Juraj Strossmayer University of Osijek, Faculty of Agriculture, Osijek, Croatia \\ ${ }^{2}$ University of Veterinary and Pharmaceutical Sciences, Brno, Czech Republic
}

Received May 20, 2008

Accepted February 9, 2009

\begin{abstract}
A 4-week experiment was carried out on 360 laying hens of the Hy Line Brown hybrid. Laying hens were divided into three groups $\left(\mathrm{C}, \mathrm{E}_{1}\right.$ and $\left.\mathrm{E}_{2}\right)$ with 120 hens in each group and kept in 24 cages. Hens were fed layer diets containing $18 \%$ of crude protein and $11.60 \mathrm{MJ} \mathrm{ME}$. Hens in the control group C were fed diets that contained $0.2 \mathrm{mg} / \mathrm{kg}$ of inorganic selenium (sodium selenite). Experimental groups $\mathrm{E}_{1}$ and $\mathrm{E}_{2}$ were given diets with increased concentrations of selenium as follows: $E_{1}=0.4 \mathrm{mg} / \mathrm{kg}$ of selenium (sodium selenite), $\mathrm{E}_{2}=0.4 \mathrm{mg} / \mathrm{kg}$ of organic selenium (SelPlex). Selenium concentration in diets affected significantly the content of selenium in albumen $(P<0.001)$ and yolk $(P<0.05)$. The highest concentration of selenium was determined in albumen and yolk of eggs produced in group $E_{2}(345 \mathrm{ng} / \mathrm{g}$ and $783 \mathrm{ng} / \mathrm{g}$, respectively), then in eggs of group $\mathrm{E}_{1}(230 \mathrm{ng} / \mathrm{g}$ and $757 \mathrm{ng} / \mathrm{g}$, respectively), and group $\mathrm{C}$ had the lowest concentration of selenium in albumen and yolk (181 ng/g and $573 \mathrm{ng} / \mathrm{g}$, respectively). After 28 days of storage at $4{ }^{\circ} \mathrm{C}$, the eggs containing organic selenium had more freshness $\left(\mathrm{VN}\right.$ : $\mathrm{C}=32.9, \mathrm{E}_{1}=2.60, \mathrm{E}_{2}=$ 2.11). It was concluded that higher concentration of organic selenium in eggs was a limiting factor in metabolic processes, which positively affected the indicators of egg freshness.
\end{abstract}

Organic selenium, inorganic selenium, albumen, yolk, egg freshness

Selenium is found in two forms in nature: inorganic and organic. Inorganic selenium refers to different minerals such as selenite, selenate and selenide, and organic selenium is related to amino acids, methionine and cysteine. Outdoor living animals that eat plants take selenium in the form of selenomethionine (SeMet) in concentrations that depend on selenium concentration in soil, which can vary considerably according to area (Reilly 1996). Klapec et al. (2004) reported low concentrations of selenium in soil on the territory of Croatia because of which the selenium content in plant and animal foodstuffs was relatively low $(\mathrm{egg}=52.5 \mathrm{ng} / \mathrm{g}$; chicken meat $=115.3 \mathrm{ng} / \mathrm{g}$; onion $=12.4 \mathrm{ng} / \mathrm{g}$; potato $=7.2 \mathrm{ng} / \mathrm{g}$ ). As a microelement, selenium has manifold importance in animal feed. Its antioxidant properties help protect animals from free radicals caused by oxygen metabolism. Moreover, selenium strengthens the immune system and boosts growth and feathering. As a dietary supplement, selenium reduces negative effects of stress in chickens kept in intensive production conditions, reduces mortality rate of one-day chickens and enhances quality of poultry products. One of the possibilities of enriching feed with selenium is to supplement it with plants fertilized with selenium (MacLeod et al. 1998). Another possibility is to supplement selenium preparations to commercial mixture fed to animals in order to design animal products that differ in their nutritive values from other conventional products available on the market.

The aim of our study was to determine the effects of supplementation of organic and inorganic selenium in increased concentrations to the hens' diet and to assess deposition of selenium in egg yolk and albumen as well as the effects of selenium on preservation of egg freshness.

\section{Materials and Methods}

The experiment was carried out on 360 Hy Line Brown laying hens of the age of 26-30 weeks. Hens were divided into three experimental groups; each group consisted of 24 repetitions. Hens were kept in cages by groups of five and fed commercial mixture containing $18 \%$ of crude protein and $11.60 \mathrm{MJ} \mathrm{ME}$. The experiment was set up in three different feeding treatments. The control group had diets supplemented with $0.2 \mathrm{mg} / \mathrm{kg}$ of selenium

Address for correspondence:

Prof.Dr.Sc.Dr.h.c. Gordana Kralik

Faculty of Agriculture

Josip Juraj Strossmayer University of Osijek

Trg svetog Trojstva 3, 31000 Osijek, Croatia

Phone. +38531224241

E-mail: gkralik@pfos.hr

http://www.vfu.cz/acta-vet/actavet.htm 
from an inorganic source (sodium selenite). Groups $E_{1}$ and $E_{2}$ were given $0.4 \mathrm{mg} / \mathrm{kg}$ of selenium ( $E_{1}$ : inorganic source of selenium; $E_{2}$ : organic source of selenium, selenomethionine - Sel-Plex ${ }^{\circledR}$, Alltech, Inc.). On the $30^{\text {th }}$ day of experiment five eggs were selected randomly from each group. The eggs were broken, and yolks and albumens were prepared for selenium analysis. The analysis was carried out as follows: The egg was broken and albumen and yolk were separated carefully from each other. Separated egg parts were homogenized. Around $0.5 \mathrm{~g}$ of homogenized sample was put in a Teflon flask for destruction. The sample was mixed with $5 \mathrm{ml}$ of concentrated $\mathrm{HNO}_{3}$ and $1 \mathrm{ml}$ of $\mathrm{H}_{2} \mathrm{O}_{2}$. After $15 \mathrm{~min}$, the tubes were closed and heated in a microwave oven (CEM, Mars 5 model). After digestion, the tube content was transferred to a $25-\mathrm{ml}$ flask and filled up with distilled water up to the line. Prior to sample preparation, all laboratory utensils were kept in a $10 \%$-solution of $\mathrm{HNO}_{3}$ for $24 \mathrm{~h}$. Selenium content in egg albumen and yolk was determined by the method of electrothermic atomic absorption spectrometry (Perkin Elmer, AAnalyst 600). Egg freshness was assessed over three different time periods (fresh eggs, eggs stored at $4{ }^{\circ} \mathrm{C}$ for 14 and 28 days) by determining values of the ageing rate (AR) and value number (VN) using the method of Kralik et al. (1990).

The AR was obtained by the following mathematical expression:

$\operatorname{AR}=\left(1.4184-\eta_{\mathrm{y}}\right) \cdot 1000$;

where: $\eta_{y}=$ refractive index of examined yolk, $1.4184=$ refractive index of standard yolk obtained from a sample of 20 eggs at a temperature of $25^{\circ} \mathrm{C}$.

The $\mathrm{VN}$ was calculated by the following expression:

$\mathrm{VN}=1000 \cdot\left(\eta_{\mathrm{y}}-\eta_{\mathrm{a}}\right)$

where: $\eta_{\mathrm{y}}=$ refractive index of examined yolk, $\eta_{\mathrm{a}}=$ refractive index of examined albumen.

Yolk and albumen refraction was determined using Refracto 30PX device. In order to calculate AR and VN, 75 eggs from each group were analyzed over three time periods. The influence of the main factors (concentration and source of selenium) on the assessed traits was determined using MANOVA (Main effects ANOVA). When the selenium source or concentration had a significant $(P<0.05)$ effect on the assessed traits, differences between the groups were tested by the Fisher's LSD-test. Analyses were performed using Statistica v.7.1 software (StatSoft, Inc., 2005).

\section{Results and Discussion}

Table 1. Content of selenium in egg albumen and yolk $(n=5)$

\begin{tabular}{|l|c|c|c|c|c|}
\hline \multirow{2}{*}{$\begin{array}{l}\text { Content of } \\
\text { selenium }\end{array}$} & \multicolumn{3}{|c|}{ Groups $\left(\bar{X}_{ \pm} \mathrm{SD}\right)$} & \multicolumn{2}{c|}{$P$ value } \\
\cline { 2 - 6 } & $\mathrm{C}$ & $\mathrm{E}_{1}$ & $\mathrm{E}_{2}$ & Source & Concentration \\
\hline $\begin{array}{l}\text { Albumen (ng of } \\
\text { selenium/g) }\end{array}$ & $181 \pm 11.8^{\mathrm{C}}$ & $230 \pm 17.4^{\mathrm{B}}$ & $345 \pm 11.3^{\mathrm{A}}$ & $<0.001$ & $<0.001$ \\
\hline $\begin{array}{l}\text { Yolk (ng of } \\
\text { selenium/g) }\end{array}$ & $573 \pm 36.2^{\mathrm{b}}$ & $757 \pm 89.1^{\mathrm{a}}$ & $783 \pm 90.9^{\mathrm{a}}$ & $<0.05$ & $<0.001$ \\
\hline
\end{tabular}

a, $P<0.05$; ${ }^{\text {A, B, }, ~} P<0.001$ Values within the row differ significantly

$\mathrm{C}=0.2 \mathrm{mg} / \mathrm{kg}$ of inorganic selenium, $\mathrm{E}_{1}=0.4 \mathrm{mg} / \mathrm{kg}$ of inorganic selenium, $\mathrm{E}_{2}=0.4 \mathrm{mg} / \mathrm{kg}$ of organic selenium

Data presented in Table 1 show that the source and concentration of selenium supplemented to the hens' diet affected selenium deposition in albumen $(P<0.001)$. The content of selenium in albumen of eggs of group $\mathrm{E}_{2}$ was higher than in groups $\mathrm{E}_{1}$ and $\mathrm{C}$ (345 $\mathrm{ng}$ of selenium/g: $230 \mathrm{ng}$ of selenium/g: $181 \mathrm{ng}$ of selenium/g, respectively). The concentration of selenium in the hens' diet has greater influence $(P<0.001)$ on the selenium content in egg yolk. The source of selenium had slightly less but still significant influence $(P<0.05)$ on the selenium content in egg yolk. Sample analysis showed that the eggs of the control group contained less selenium in yolks than groups $\mathrm{E}_{1}$ and $\mathrm{E}_{2}(573 \mathrm{ng}$ of selenium $/ \mathrm{g}: 757$ $\mathrm{ng}$ of selenium/g : $783 \mathrm{ng}$ of selenium $/ \mathrm{g}$, respectively). Based on the results stated above it was concluded that plants should be enriched with selenium in order to provide animal diets with higher concentrations of organic selenium as it is absorbed through membranes of the intestinal tract and actively accumulated in the organism cells. Humans and animals cannot synthesize selenomethionine in their organisms, so it is necessary to ensure selenium intake through diets (Schrauzer 2000). Producers usually supplement sodium-selenite (inorganic source of selenium) to animal feed; however, inorganic selenium cannot be fully used by an organism and is mostly excreted. Therefore, it is important to emphasize advantages of organic selenium in comparison to inorganic selenium. 
Cantor et al. (1996) studied the effects of selenium (inorganic and organic; $0.3 \mathrm{mg} / \mathrm{kg}$ ) supplemented to the hens' diet on the selenium content in egg and reported a significant effect of selenium concentration in diet on its content in egg, which corresponds with our results. Moreover, Payne et al. (2005) pointed out that different sources of selenium (inorganic or organic) and concentrations of selenium in the feed $(0 ; 0.15 ; 0.3 ; 0.6$ and $3 \mathrm{mg} / \mathrm{kg})$ significantly affected $(P<0.01)$ content of selenium in egg. The authors stated that the concentration of selenium in eggs was increased in proportion to the concentration of selenium in the diet $(P<0.01)$. Their results are also in accordance with ours. Surai (2000) stated that supplementation of organic selenium to the hens' diet could significantly increase the selenium content in egg yolk and albumen $(P<0.01)$. He also reported a high correlation coefficient between selenium concentrations in the hens' diet and in eggs. Cantor (1997) and Paton et al. (2000) also confirmed relations between source and concentration of selenium in diets and selenium concentration in eggs.

Table 2. Ageing rate and value number for eggs stored for 28 days at $4{ }^{\circ} \mathrm{C}(\mathrm{n}=75)$

\begin{tabular}{|l|c|c|c|c|c|c|}
\hline \multirow{2}{*}{ Groups } & \multicolumn{4}{|c|}{ Time period of egg storage at $4^{\circ} \mathrm{C}$} \\
\cline { 2 - 8 } & \multicolumn{2}{|c|}{1 day } & \multicolumn{2}{c|}{14 days } & \multicolumn{2}{c|}{28 days } \\
\cline { 2 - 8 } & AR & VN & AR & VN & AR & VN \\
\hline $\mathrm{C}$ & $1.07 \pm 1.27$ & $60.20 \pm 2.17$ & $1.82 \pm 1.23$ & $59.44 \pm 1.63$ & $3.29 \pm 1.35^{\mathrm{a}}$ & $57.51 \pm 1.35$ \\
\hline $\mathrm{E}_{1}$ & $1.24 \pm 1.42$ & $60.50 \pm 1.53$ & $2.30 \pm 2.10$ & $59.37 \pm 2.06$ & $2.60 \pm 1.41^{\mathrm{ab}}$ & $58.22 \pm 2.07$ \\
\hline $\mathrm{E}_{2}$ & $0.94 \pm 1.06$ & $60.60 \pm 1.66$ & $1.55 \pm 1.48$ & $60.30 \pm 2.62$ & $2.11 \pm 1.29^{\mathrm{b}}$ & $58.44 \pm 2.04$ \\
\hline$P$ value & $>0.05$ & $>0.05$ & $>0.05$ & $>0.05$ & $<0.05$ & $>0.05$ \\
\cline { 2 - 8 } & $>0.05$ & $>0.05$ & $>0.05$ & $>0.05$ & $<0.01$ & $>0.05$ \\
\hline
\end{tabular}

a, b $P<0.01$ Values within the row differ significantly

$\mathrm{C}=0.2 \mathrm{mg} / \mathrm{kg}$ of inorganic selenium, $\mathrm{E}_{1}=0.4 \mathrm{mg} / \mathrm{kg}$ of inorganic selenium, $\mathrm{E}_{2}=0.4 \mathrm{mg} / \mathrm{kg}$ of organic selenium

Egg freshness is related to its quality. It depends on the egg storage period (counted in days) and on conditions under which the eggs are stored (temperature and relative air humidity). There are many indicators that show changes occurring as a consequence of egg storage. Longer period of storage increases AR and decreases VN. Table 2 shows changes in AR and VN of eggs of all three groups over the period of 28 days. In our experiment, the AR values were increased over the 28-day period; however, the differences between groups in were not significant $(P>0.05)$ for the first two periods $\left(1^{\text {st }}\right.$ and $14^{\text {th }}$ day). After storing eggs at $4{ }^{\circ} \mathrm{C}$ for 28 days, the highest $\mathrm{AR}$ was determined for group $\mathrm{C}$ (3.29), followed by group $\mathrm{E}_{1}(2.60)$, and the least $\mathrm{AR}$ was exhibited by group $\mathrm{E}_{2}$ (2.11). Determined differences regarding $\mathrm{AR}$ of investigated eggs after 28-day storage were significant. The source and concentration of selenium in hens' diets influenced the determined differences in AR $(P<$ 0.05 and $P<0.01$, respectively). In the course of egg ageing, the concentration of egg mass is reduced. Water contained in albumen permeates the yolk, and some nutrients contained in yolk can permeate albumen. These osmotic tracks and changes in albumen and yolk concentrations can be measured by the refractometric method. Metabolic processes in eggs of group $\mathrm{E}_{2}$ were less intensive, so $\mathrm{AR}$ in that group was the lowest over the whole storage period, and the VN was the highest. Kralik et al. (1990) measured the mean of AR of fresh eggs 0.92, which corresponds to AR of group $E_{2}$. Rotruck et al. (1973) proved selenium to be a part of glutathione peroxidase enzymes (GSH-Px), which confirmed its role in cellular antioxidative metabolism. Wakebe (1999) emphasized positive effects of dietary supplementation with organic selenium at the concentration of $0.3 \mathrm{mg} / \mathrm{kg}$ of feed on the activity of GSH-Px enzymes. Its presence reduces occurrence of free radicals that intensify metabolic processes in cells (oxidation of lipids and proteins) and reduce activity of enzymes of polymerase, nuclease, ligase, etc. Changes that occur through intensified metabolic processes in the egg have negative effects on preservation of egg freshness. In 
our study, the highest $\mathrm{VN}$ was measured in fresh eggs of group $\mathrm{E}_{2}$, then of group $\mathrm{E}_{1}$, and $\mathrm{C}$ group had the least VN (60.60:60.50:60.20, respectively), which is in accordance with the results of Kralik et al. (1990). On the $14^{\text {th }}$ and $28^{\text {th }}$ day of egg storage, VN was still the highest in group $\mathrm{E}_{2}$. The influence of source and concentrations of selenium were not significant $(P>0.05)$ regarding VN of the examined groups. Sources and different concentrations of selenium in hens' diets resulted in the increase of the selenium content of egg albumen $(P<0.001)$ and yolk $(P<0.05$ and $P<0.001$, respectively). Analysis of $\mathrm{AR}$ and $\mathrm{VN}$ of eggs exhibited more favourable values for eggs produced by hens that were fed diets containing organic selenium compared to eggs from hens fed diets with inorganic selenium. The source and concentration of selenium in hens' diets did not influence the differences in VN between groups, however, both factors had a significant effect on AR of eggs after they were stored for 28 days at $4{ }^{\circ} \mathrm{C}(P<0.05$ and $P<0.01$, respectively).

\section{Vliv dietních zdrojů selenu na skladování a kvalitu vajec}

Čtyřtýdenní pokus se uskutečnil na 360 nosnicích hybridu Hy Line Brown. Nosnice byly rozděleny po 120 kusech do tří skupin $\left(\mathrm{C}_{1} \mathrm{E}_{1}\right.$ a $\left.\mathrm{E}_{2}\right)$ a drženy v 24 klecích. Byly krmeny dietami, které obsahovaly $18 \%$ dusíkatých látek a 11,6 MJ ME. Nosnice kontrolní skupiny byly krmeny dietou, která obsahovala $0,2 \mathrm{mg} / \mathrm{kg}$ anorganického selenu (selenit sodný). Pokusné skupiny $\mathrm{E}_{1}$ a $\mathrm{E}_{2}$ měly v dietě vyšší koncentraci selenu; skupina $\mathrm{E}_{1} 0,4 \mathrm{mg} / \mathrm{kg}$ selenitu sodného, skupina $\mathrm{E}_{2} 0,4 \mathrm{mg} / \mathrm{kg}$ organického selenu (prípravek Sel-Plex). Selen v dietách ovlivnil významně hladiny selenu ve vaječném bílku $(P<0,001)$ a vaječném žloutku $(P<0,05)$. Nejvyšší koncentrace selenu byly nalezeny ve vaječném bílku a žloutku vajec skupiny $E_{2}(345$ a $783 \mathrm{ng} / \mathrm{g})$, následovaly vejce skupiny $\mathrm{E}_{1}$ (230 a 757 ng/g), nejnižší hodnoty byly zjištěny u kontrolní skupiny (181 a 573 ng/g). Po 28 dnech skladování při teplotě $4{ }^{\circ} \mathrm{C}$ byla čerstvost nejpříznivější u vajec obsahující organicky vázaný selen $\left(\mathrm{VN}: \mathrm{C}=32,9, \mathrm{E}_{1}=2,60, \mathrm{E}_{2}=2,11\right)$. Vyšší koncentrace organického selenu byla limitujícím faktorem metabolických procesứ, které pozitivně ovlivnily indikátory čerstvosti vajec.

\section{References}

Cantor AH, Pescatore AJ, Straw ML, Ford MJ 1996: Effects of selenium yeast (Sel-Plex) on egg selenium concentrations. 1. Sel-Plex vs selenite. pp. 155-164. In: Biotechnology in the Feed Industry. Proceedings of Alltech's Twelfth Annual Symposium, Ed. Lyons, T.P. and Jacques, K.A., Nottingham University Press, Nottingham, UK, 376 p.

Cantor AH 1997: The role of selenium in poultry nutrition. pp. 155-164 In: Biotechnology in the Feed Industry. Proceedings of Alltech's thirteenth Annual Symposium, Ed. Lyons, T.P. and. Jacques, K.A., Nottingham University Press, Nottingham, UK, $441 \mathrm{p}$.

Klapec T, Mandić ML, Grgić J, Primorac LJ, Perl A, Krstanović V 2004: Selenium in selected foods grown or purchased in eastern Croatia. Food Chem 85: 445-452

Kralik G, Komendanović V, Petričević A 1990: Physico-chemical properties of eggs. Options Méditerranéennes, Ser. A - L’aviculture en Méditerranee 7: 245-247

MacLeod JA, Gupta UC, Milburn P, Sanderson JB 1998: Selenium concentration in plant material, drainage and surface water as influenced by Se applied to barley foliage in a barley-red clover-potato rotation. Can J Soil Sci 78: 685-688

Paton ND, Cantor AH, Pescatore AJ, Ford MJ 2000: Effect of dietary selenium source and length of storage on internal quality and shell strength of eggs. Poult Sci 79: 75

Payne RL, Lavergne TK, Southern LL 2005: Effect of inorganic versus organic selenium on hen production and egg selenium concentration. Poult Sci 84: 232-237

Reilly C 1996: Selenium in food and health. Blackie Academic \& Professional, London.

Rotruck JT, Pope AL, Ganther HE, Swanson AB, Hofeman DG, Hoekstra WG 1973: Selenium: biochemical role as a component of glutathione peroxidase. Science 179: 588-590

Schrauzer NG 2000: Selenomethionine: a review of its nutritional significance, metabolism and toxicity. J Nutr 130: $1653-1656$

StatSoft, Inc. 2005: Statistica (data analysis software system), version 7.1. www.statsoft.com.

Surai PF 2000: Organic selenium and the egg: lessons from nature. Feed Compounder 20: 16-181

Wakebe M 1999: Organic selenium and egg freshness. Patent 10-23864. Japanese Patent Office, Application Heisei 8-179629. In: Biotechnology in the Feed Industry. Proceedings of Alltech's Fifteenth Annual Symposium, Ed. Lyons, T.P. and. Jacques, K.A., Nottingham University Press, Nottingham, UK, 595 p. 